\title{
Determination of the optimal inactivation time of FMD virus Type " $A$ " using BEI inactivator during the outbreak 2006 in Egypt and its effect on the antigenicity of the virus
}

\author{
A. A. Omar, H. M. A. Azab, M. M. Abdel-Aty, S. M. Ali, M. A. Farag \\ Veterinary Serum and Vaccines Research Institute Abbassia, Cairo.Egypt.
}

\begin{abstract}
FMD virus type A/1/ Egypt 2006 was inactivated with 0.1 M of BEI (Binary ethylene imine) formed by cyclization of 2- Bromoethyl-amine hydrobromide (BEA) in $0.2 \mathrm{~N} \mathrm{NaoH} \mathrm{at} 37^{\circ} \mathrm{C}$ with PH 8.0 for 24 hours. The virus was complete inactivated after 15 hours post inactivation. No residual virus particles were detected when inoculated in tissue culture. The inactivation rates are linear with a regular loss of ${ }^{\text {titer }}$ ranged from $0.5-1.0 \log _{10} /$ hour. Control sample of virus at $37^{\circ} \mathrm{C}$ without BEI showed only a loss of $1.0 \mathrm{log}$ from the original infectivity titer after 24 hours. The sample of virus which kept at $-20^{\circ} \mathrm{C}$, without BEI, showed loss $0.3 \log _{10}$ from its original infectivity titer after 24 hours. There is no change in the complement fixing antigen before and after inactivation process with BEI inactivator and in the CFT $1 / 8$ dilution of antigen was stable (fixed) pre and post inactivation of virus. Also it was found that the inactivation rate of BEI was higher than the inactivation with pure Ethylenimine (EI) and formalin.
\end{abstract}

The first widely used FMD vaccine was in the form of virus inactivated with formalin the formation of inactivated virus with formaline is still in use in several vaccine producing companies. A residual infectivity remained or the preparation lost its immunizing potency by using formalin inactivation (Wald man et al., 1937). It has been recognized early that formalin vaccines, although innocuous, might contain effective virus (Moosbrugger, 1948). Wild and Brown (1968) found evidence that formalin altered the structure of the virion. Also formalin does not produce a first-order kinetic reaction when inactivating the virus (Wesslon and Dinter, 1957).

For all these reasons, an the less confidence in the formaldehyde treatment forced many production laboratories change to aziridine i.e. Acetylethyleimine (AEI) as inactivator (Brown and Newmann 1963) and more recently ethylethyeneimine (EEI) is considered among the latest inactivates as it destroys the infectivity of the virus by a first order reaction without any apparent damage, even after several months Bauer., (1970). However, AEI has the inconvenience of being unstable at room temperature and AEI as well as EEI are highly toxic and their use requires special precautions. Bahnemann., (1975) used 2- bromo ethylamine hydromide in alkaline solution to reduce the toxicity of Ethyleneimine (EI). It is called Binary ethyleneimine (BEI) and when used in FMD preparation of its immunogenicity was similar to the identical vaccines inactivated with (AEI) (Bahnemann et al., 1974). The validation of BEI when used as an inactivant is essential to ensure the quality of the inactivating agent and the validity of the process. The inactivation kinetics of FMD virus Type (O, A and Asia 1) were determined for different concentrations of BEI and the results indicated that no differences in the inactivation kinetics between the various types in the studies (Aarthi et al., 2004).

The aim of the present study is directed to determine the optimal inactivation time of FMD virus Type (A) recently isolated in the last 2006 outbreak in Egypt using BEI as inactivator by studying the inactivation kinetics of BEI on type (A) FMD virus.

\section{Materials and methods}

FMDV. type A/1 Egypt 2006

FMD virus. The virus used in this study was FMD virus Type A/1 Egypt 2006 isolated from 2006 outbreak Ismailia province. It was 7 times serially passaged in Baby Hamster Kidney (BHK21) monolayer cell cultures. The virus harvest stored at $-70^{\circ} \mathrm{C}$.

Tissue cultures. a) Baby Hamster Kidney cell cultures $\left(\mathrm{BHK}_{21}\right)$ was obtained from The World Reference Lab. Pirbright surrey, England. The cells were serially passaged and maintained in 
the FMD Department at the Veterinary Serum and Vaccine Institute, Abbassia, Cairo.

b) Primary cell kidney cultures (BK) were prepared according to the method described by Patty (1965).

Chemical inactivator. 2-Bromoethyl-amine hydrobromide (BEA) 95\% ( molecular weight $=$ 204.9) obtained from Aldrich Chemical Company Limited Gillinham, Dorest, England.

Sodium Hydroxide (analar) $(\mathrm{NaOH})$ ( Molecular weight $=40$ ) obtained from PRATAP chemical industries PVT.LTD (INDIA) was used in concentration 0.2 Normal in inactivation process according to Bahnemann H.G.,(1975)

Titeration of infectivity of FMD virus (Type A). In tissue culture and Baby mice and the infectivity titer was calculated according to (Karber's Method 1931).

Complement fixation test (CFT). It was carried out according to Traub and Manso (1944).

Samples of virus. Samples were taken prior, during and after inactivation and for titration and CFT for detection of residual virus infectivity and testing its antigenicity respectively.

Sodium thiosulphate $\left(\mathrm{Na}_{2} \mathrm{~S}_{2} \mathbf{O}_{3} \quad \mathbf{5 H}_{2} \mathbf{O}\right) .20 \%$ solution in double distilled water was prepared and sterilized by autoclaving. The chemical obtained from Merck Company, Germany. It was used in final $2 \%$ concenrtation after inactivation of virus and its molecular weight $=248.18$, as described by Girard et al., (1977).

Inactivation of FMDV. Type (A) with Bei. BEI can be easily prepared by adding $2 \%$ of the salt (exactly $0.1 \mathrm{M}$ ) in pre warmed $0.2 \mathrm{~N}$. $\mathrm{NaOH}$ and keeping the solution for 1 hour at $37^{\circ} \mathrm{C}$. This BEI solution can be easily kept at room temperature, with $1 \%$ of $0.1 \mathrm{M} \mathrm{BEA}$ solution that is to say at a final BEI concentration of $0.001 \mathrm{M}$, inactivation of $\mathrm{FMDV}$ at $37^{\circ} \mathrm{C}$ is completed within 24 hours at pH8.0 Sodium thiosulphate $(20 \% \mathrm{~W} / \mathrm{V})$ was added to samples during and after inactivation in final concentration of $2 \%$.

\section{Results and discussion}

The rate of inactivation kinetics of FMDV, (Type A/1 Egypt 2006) by BEI is represented in Table (1) and Fig. (1) Where complete inactivation of the virus was a achieved after 15 hours. With no residual virus was detected in tissue cultures and the inactivation rate was linear. There was a regular loss ranged from 0.5$1.0 \log _{10} /$ hour and the control sample at $37^{\circ} \mathrm{C}$ without BEI showed only a loss of $1 \log _{10}$ from the original infectivity after $24 \mathrm{hrs}$. Also the sample which was kept at $-20^{\circ} \mathrm{C}$ without BEI also showed only loss $0.3 \log _{10}$ from its original infectivity after 24 hours.

(Bahnemann 1975) recorded higher inactivation rates with BEI than with pure EI thus indicating that the cyclization of BEA is very efficient and may also reflect a slight degree of polymerization of EI. A preparation of $0.1 \mathrm{M}$ BEI contains only $0.5 \%$ EI. This eliminates the problem of vapour inhalation and greatly reduces the danger of conact toxicity .However, a protection of face as well as hands and arms against accidental contact is still indicated when large volumes of $0.1 \mathrm{M}$ preparation are handled in the inactivation procedures.

Table (2) showing that there is no difference in CF- titer of the FMD virus before and after inactivation with BEI. where the original sample titer did not changed from $1 / 8$. This indicates that the BEI has no any detrimental effect on the antigenicity of inactivated virus this results were in agreement with that obtained by (Girard et $a$., 1977) who found that the direct action of formalin disrupts the protein coat of virus, however, the $\mathrm{O}_{1}$ strain is stabilized by BEI inactivation to such an extent that the consequent addition of formalin could eventually secure a longer duration of the vaccine potency.

It could be concluded from the previous results that the BEI inactivation range of FMDV. Type A/1 Egypt 2006 was completely achieved after 15 hours and the antigenic content of this virus was not changed before and after inactivation process was $1 / 8 \mathrm{CF}$ titer so FMD vaccine prepared and inactivated with BEI is more immunogenic. Therfore it improve the quality of FMD vaccine (Pichit et al., 1985). Also our results were confirmed by the results obtained by (Omar et al., 1990) who found that FMD vaccine inactivated with BEI was better in quality than the formalin inactivated one. 
Table (1) Inactivation Kinetics of FMDV. Type A/1 Egypt 2006 with BEI at $37^{\circ} \mathrm{C}$ for $24 \mathrm{hrs}$ at pH 8.0.

\begin{tabular}{|c|c|c|c|c|}
\hline Starting titer & $\begin{array}{l}\text { Reaction } \\
\text { time }\end{array}$ & $\begin{array}{c}\text { Inactivator } \\
\text { concentration (BEI) }\end{array}$ & Temperature & $\begin{array}{c}\text { Virus titer after } \\
\text { inactivation } \log _{10} / \mathrm{ml}\end{array}$ \\
\hline \multirow{13}{*}{$10^{7.5}$} & 0 hours & $\begin{array}{c}0.1 \mathrm{M} \text { in } 0.2 \mathrm{~N} \\
\mathrm{NaoH} \text { at } \mathrm{pH} 8.0\end{array}$ & $37^{\circ} \mathrm{C}$ & $10^{7.5}$ \\
\hline & 3 hours & & $37^{\circ} \mathrm{C}$ & $10^{6.9}$ \\
\hline & 6 hours & & $37^{\circ} \mathrm{C}$ & $10^{5.3}$ \\
\hline & 9 hours & & $37^{\circ} \mathrm{C}$ & $10^{3.7}$ \\
\hline & 12 hours & & $37^{\circ} \mathrm{C}$ & $10^{2.1}$ \\
\hline & 15 hours & & $37^{\circ} \mathrm{C}$ & $10^{0}$ \\
\hline & 18 hours & & $37^{\circ} \mathrm{C}$ & 0 \\
\hline & 19 hours & & $37^{\circ} \mathrm{C}$ & 0 \\
\hline & 20 hours & & $37^{\circ} \mathrm{C}$ & 0 \\
\hline & 21 hours & & $37^{\circ} \mathrm{C}$ & 0 \\
\hline & 22 hours & & $37^{\circ} \mathrm{C}$ & 0 \\
\hline & 23 hours & & $37^{\circ} \mathrm{C}$ & 0 \\
\hline & 24 hours & & $37^{\circ} \mathrm{C}$ & 0 \\
\hline \multirow{2}{*}{$\begin{array}{l}\text { Control virus } \\
\text { without BEI }\end{array}$} & 24 hours & Without BEI & At $37^{\circ} \mathrm{C}$ & $10^{6.5}$ \\
\hline & 24 hours & Without BEI & At $-20{ }^{\circ} \mathrm{C}$ & $10^{7.2}$ \\
\hline
\end{tabular}

N.B. $B E I=($ Binary ethyleneimine $)$

Fig. (1): Inactivation Kinetics of FMDV type A /1/ Egypt 2006 with BEI at 37 C for 24 hours at PH 8

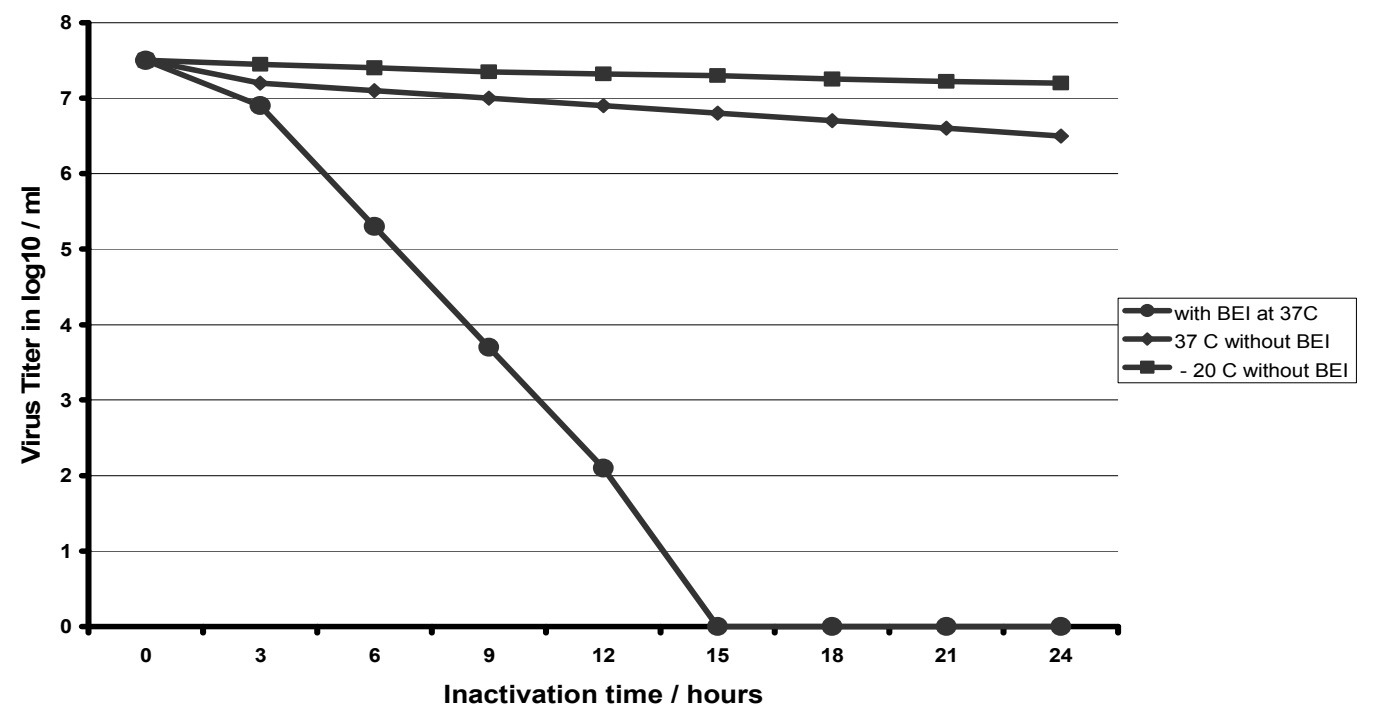


Table (2) Effect of BEI inactivation on complement fixing antigenicity of FMDV Type A/1 Egypt 2006.

\begin{tabular}{|c|c|c|c|}
\hline \multirow{2}{*}{ Starting titer } & \multirow{2}{*}{$\begin{array}{c}\text { Inactivation time / } \\
\text { hours at } 37 \mathbf{C}^{\mathbf{0}}\end{array}$} & \multicolumn{2}{|c|}{ CFT*/ titer } \\
\hline & & $\begin{array}{c}\text { Before } \\
\text { Inactivation }\end{array}$ & $\begin{array}{c}\text { After } \\
\text { Inactivation }\end{array}$ \\
\hline \multirow{13}{*}{$10^{7.5}$} & 0 hours & $1 / 8$ & $1 / 8$ \\
\hline & 3 hours & $1 / 8$ & $1 / 8$ \\
\hline & 6 hours & $1 / 8$ & $1 / 8$ \\
\hline & 9 hours & $1 / 8$ & $1 / 8$ \\
\hline & 12 hours & $1 / 8$ & $1 / 8$ \\
\hline & 15 hours & $1 / 8$ & $1 / 8$ \\
\hline & 18 hours & $1 / 8$ & $1 / 8$ \\
\hline & 19 hours & $1 / 8$ & $1 / 8$ \\
\hline & 20 hours & $1 / 8$ & $1 / 8$ \\
\hline & 21 hours & $1 / 8$ & $1 / 8$ \\
\hline & 22 hours & $1 / 8$ & $1 / 8$ \\
\hline & 23 hours & $1 / 8$ & $1 / 8$ \\
\hline & 24 hours & $1 / 8$ & $1 / 8$ \\
\hline
\end{tabular}

${ }^{*} \mathrm{CFT}=$ Complement Fixation Test._The titer of CFT was not changed after inactivation process even_after 24 hours.

\section{References}

Aarthi D.,Ananda Raok , Robinson R., Srinivasan VA., (2004): Validation of Binary ethyleneimine (BEI) used as an inactivant for FMD tissue culture vaccine. Biologicals. 2004 Sept; 32(3):153-6. Indian Immunologicals limited, Gachibowli, Hyderabad 500019, India.

Abdel-Aty,M.M.,(1993): Further studies on FMD Vaccine in Egypt. Ph.D. Thesis, Infectious diseases Dept.Faculty of Vet.Med.,Cairo University.

Bahnemann H.G., Auge de. Mello P., Abaracon D. and Gomes I. (1974): Immunogenicity in cattle of FMD vaccine inactivated with Binary ethyleneimine. Bull. Off. Int. Epiz. 81, 1335-1343.

Bahnemann H.G. (1975): Binary ethyleneimine as an inactivant for FMDV. and its application for vaccine production. Arch. Virol. 47, 47-56.

Bauer K. (1970): Die Inaktivierung des Maul-und Kleauen seuche virus durch A cethylaethylenei-mine und die Eignung des inaktivierung virus zur Impfstoffherstellung zbt. Bakt. I. Orig 213,258-297.

Brown,F. and Newmann,J.FE.,(1963): In vitro measurement of potency of inactivated FMDV. Vaccines. J.Hyg. Comb., 61: 345-351.

Girard H.C., Bayramogh O., Erol N. and Burgut A. (1977): Inactivation of $\mathrm{O}_{1}$ FMD virus by the Binary ethyleneimine (BEI). Bull. Off. Int. Epiz. 87(3-4)201-217.

Karber G. (1931): Beitung Zurkillk-iven Behand Lung pharmakologi Reihen ver suche Naugn Schmide berg's. Arch. Exp. Path. Pharmak. 162:280-283.
Moosburgger G.A. (1948): Recherechesexperimentales surla Fievre Aphteuse. Schwiezer Arch. FurTierheilk, 90,176-178.

Omar, A.; Bakr, A.; Abdel-Samea, M.M. and Badr, S. (1990): Inactivation of FMDV. by Aziridine and formalin. Zagazig Vet. J., Vol.18:No.3 P.8-15.

Patty, R.E. (1965): A simplified method for preparing bovine kidney cells for growth on glass. Amer. J. Vet. Res., 25:787-789.

Pichit, M.; Payont, S.; and Panan, T.; (1985): Binary ethyleneimine and FMD vaccine production Vet. Viral Diseases: their significance in South East Asia and Western Pacific. Copy right (C) 1985 by Academic Press, Australia.

Traub, E. and Manso, I.R. (1944): uber die herstellung Komplement bindender meersch weinchonsera für die typen diagnose bei maul und klauenceuche. Zbl. Bakt. I. org; 151:380-392.

Waldman, O.; Koe, K. and Pyl, G. (1937): Die Ative Immunisierung des rindes gegen Maul und Klauenche mittels formal impfstoff zentrable. Bakt. L. Abt. Orig; 138:401-412.

Wesslen, T. and Dinter, Z.(1957): the inactivation of FMDV. by formalin. Vet. Inst. Stock. Inst. Hyg. Bact.; 25:394-402

Wild, T.F. and Brown, F. (1968): A study of the physical properties of the immunizing antigen of FMD virus and the effect of the various inactivating agents on its structure. Arch. Ges. Virus for Sch.2 4, 86-103 
تأثير المحفز المناعي مستخلص البروبيونوباكتريم والليبوبولي سكاريد لميكروب الإيشريشيا كولاي( إنميونير ه, V ) على الإستجابة المناعية للأرانب المحصنة بلقاح النزف الدموي الفيروسي الأرنبي

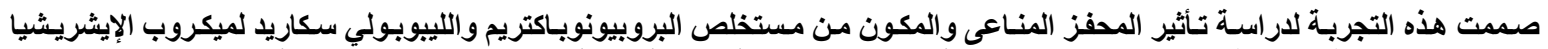

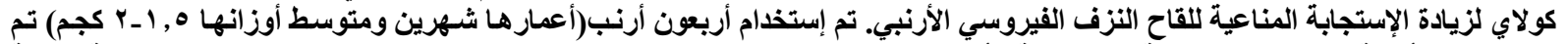

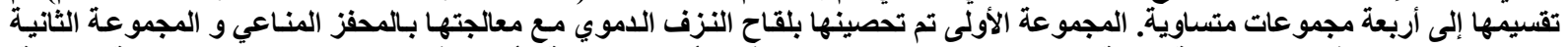

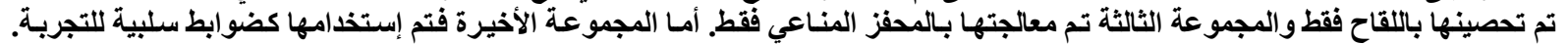

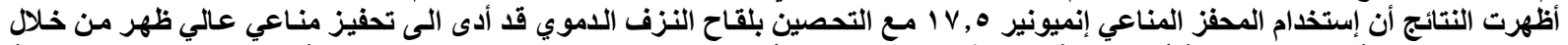

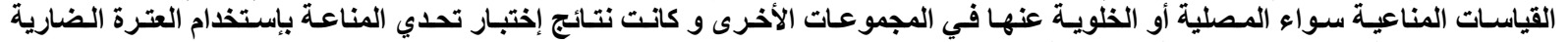
للفيروس متوافقة مع النتائج المناعية و المئة الخلوية. 